\title{
Effects of Suspension Hypokinesia/Hypodynamia on the Body Weight and Nitrogen Balance in Rats Fed with Various Protein Concentrations ${ }^{\dagger}$
}

\author{
Hidehiko YoKogoshI, ${ }^{\dagger \dagger}$ Sachiko TAKaSE, ${ }^{*}$ Toshinao GodA ${ }^{*}$ \\ and Takeshi HosHi** \\ Laboratory of Nutritional Biochemistry, * Laboratory of Nutritional Physiology, \\ and ${ }^{* *}$ Laboratory of Physiology, School of Food and Nutritional Sciences, \\ The University of Shizuoka, Shizuoka 422, Japan
}

Received October 20, 1989

\begin{abstract}
Hypokinesia/hypodynamia was induced in the hindlimbs of rats by means of a suspension harness, and metabolic balance studies, especially regarding nitrogen, were performed with different dietary protein levels $(5,10,20,40$ and $60 \%$ casein diets). During a 10-day period of hypokinesia, significant reductions in the food intake and body weight were observed, especially with the high protein $(60 \%$ casein) diet. However, the total nitrogen balance was positive (only in the first 1-2 days was the nitrogen balance negative in the suspended rats fed with the low-protein ( $5 \%$ casein) diet), even with the 5 or $10 \%$ protein diet, and the body protein content was also increased, as compared with that in the non-suspended rats. On the other hand, as a significant decrease in body fat was observed, the loss of body weight may have been mainly due to this fat decomposition. Hindlimb muscle atrophy (gastrocnemius and soleus) and also adrenal hypertrophy were observed. It may be considered that suspension causes glucocorticoid-mediated muscle catabolism. These results show that significant muscle atrophy and parallel changes in nitrogen metabolism occur in suspended rats, and an investigation of the mechanism underlying these changes by suspension may provide a new approach for crew health in space flight or to a solution of the many different problems from prolonged bed rest.
\end{abstract}

Muscle atrophy is characteristic of the prolonged hypokinesia resulting from restricted movement, prolonged bed rest, limited muscular function and immobilization. ${ }^{1-7)}$ The causes may be disuse, inadequate functional loading, insufficient food intake and lack of exercise. ${ }^{8)}$ Space flight may be associated with more than one of these conditions, because the absence of gravity favors the diminished use of the lower limbs for postural support and locomotion, reduced loading on weight-bearing tissues, and interference with proprioreceptor reflexes, which can influence muscle metabolism and function. ${ }^{9,10}$ ) With reduced loadbearing of the musculoskeletal system under conditions of weightlessness (both astronauts and cosmonauts), a loss of nitrogen has been demonstrated..$^{8-12)}$ Prolonged immobilization also leads to a negative nitrogen balance. ${ }^{1)}$ However, according to Skylab data, a negative nitrogen balance developed in flight and then persisted for 3 weeks, but after about a month, the nitrogen balance varied from negative to slightly positive. ${ }^{13)}$ Little is understood about the mechanism underlying weightlessness and a negative nitrogen balance. Some of the weight loss change may also be attributed to dietary effects. It is very important to study the mechanism underlying the hypokinesia/ hypodynamia effect on skeletal unloading, because such examinations will contribute to flight crew health and safety before, during and

This work was supported in part by a Grant-in-Aid for Scientific Research from the Ministry of Education, Science and Culture of Japan.

${ }^{\dagger+}$ Address for correspondence: Laboratory of Nutritional Biochemistry, School of Food and Nutritional Sciences, The University of Shizuoka, 395 Yada, Shizuoka 422, Japan. 
after space missions, and offer a solution to the many physiological problems from prolonged bed rest.

In this study, we examined short-term hypokinesia with an animal model in relation to the effect of concentrations of dietary proteins on body weight, organ weight, nitrogen balance and body composition.

\section{Materials and Methods}

Animals and diets. Young adult male rats*1 of the Wistar strain (about $130 \mathrm{~g}$ ) were fed on a commercial stock diet*2 for 5 days for adaptation to the new environment. The following morning, the rats were divided into six groups (five rats per group) and, under light anesthesia with ethyl-ether, the experimental rats of five groups were each placed in a suspension harness made of denim material and fastening tape (Fig. 1). One group of rats was not suspended for use as the non-suspended control. The denim harness was cut to fit around the torso, the legs extending through openings. This denim suit was fastened with tape on the dorsal surface and held by clips to conform to the dorsal surface of the animal. This unit was attached to a swivel that was suspended by chains from hooks in a metabolism cage to enable the collection of urine and feces. The suspended rat was able to use its forelimbs to eat food and to drink water, the hindlimbs hanging free and thus being non-load bearing. This suspension apparatus is a modified version of a type used by Musacchia et al. ${ }^{14)}$ The rats were fed on a test diet with different protein contents, the percentage compositions of which are shown in Table I, for 10 days. Urine and feces were collected for 2 -day periods. The room temperature was maintained at $24^{\circ} \mathrm{C}$ with a 12 -hr light (between 0700 and $1900 \mathrm{hr}$ ) and dark cycle. All the rats were individually supported or housed, and weighed every 2 days during the experimental period.

Experiment. The suspended rats were fed on a 5, 10, 20, 40 or $60 \%$ casein diet, and the non-suspended rats on a $20 \%$ casein diet, each for 10 days. On the morning of day 10 , the rats were decapitated, and some organs were immediately removed, frozen on dry ice and then stored at $-70^{\circ} \mathrm{C}$ until assayed. Blood was collected from the cervical wound and serum samples were stored at $-20^{\circ} \mathrm{C}$ until assayed. Urine and feces were collected for 2-day periods, and the nitrogen contents of the urine, feces and the test diet were determined by the semimicro-Kjeldahl method. ${ }^{* 3}$ Carcass lipids were extracted by the method of
Table I. Composition of the Basal Diet

$\begin{array}{lc} & (\%) \\ \text { Protein } & 20.0 \\ \text { Corn oil } & 5.0 \\ \text { Mineral mixture }^{a} & 5.0 \\ \text { Vitamin mixture }^{b} & 1.0 \\ \text { Choline-Cl }_{\text {Carbohydrate (starch }: \text { sucrose }=2: 1)} & 0.15 \\ & 68.85\end{array}$

a The salt mixture for the diet had the following percentage composition: $\mathrm{CaHPO}_{4}, 50.0 ; \mathrm{NaCl}, 7.4$; $\mathrm{K}_{3} \mathrm{C}_{6} \mathrm{H}_{5} \mathrm{O}_{7} \cdot \mathrm{H}_{2} \mathrm{O}, 22.0 ; \mathrm{K}_{2} \mathrm{SO}_{4}$. 5.2; $\mathrm{MgO}, 2.4$; $\mathrm{MnCO}_{3}, 0.35 ;$ Fe-citrate, $0.6 ; \mathrm{ZnCO}_{3}, 0.16 ; \mathrm{CuCO}_{3}$, $0.03 ; \mathrm{KIO}_{3}, 0.001 ; \mathrm{Na}_{2} \mathrm{SeO}_{3}, 0.0007 ; \mathrm{CrK}\left(\mathrm{SO}_{4}\right)_{2}$. $12 \mathrm{H}_{2} \mathrm{O}, 0.055$; sucrose, 11.8033 .

$b$ The vitamin mixture for the diet had the following percentage composition: thiamine $\mathrm{HCl}, 0.06$; riboflavin, 0.06 ; pyridoxine $\cdot \mathrm{HCl}, 0.07$; nicotinic acid, 0.3 ; calcium pantothenate, 0.16 ; folic acid, 0.02 ; biotin, 0.002 ; vitamin $\mathrm{B}-12,0.0001$; retinyl palmitate, 0.022 ; DL- $\alpha$-tocopherylacetate, 0.50 ; cholecalciferol, 0.00025 ; vitamin $\mathrm{K}$ (menadione), 0.0005 ; sucrose, 98.80515

Folch et $a l^{15)}$ and used for a gravimetric determination of total lipids. Serum protein and albumin were determined spectrophotometrically. ${ }^{4,16)}$

Statistical analysis. The statistical significance of the differences between values was determined by the Student $t$-test (in some cases), an analysis of variance and Duncan's multiple range test. ${ }^{[7\}}$

\section{Results}

Effects of suspension on the body weight and food intake in rats fed on a diet with different protein contents

The body weight of the suspended rats decreased, especially in the group of rats fed on the high protein $(60 \%$ casein) diet; however, when the rats were fed on the $10 \%$ casein diet for 10 days, the body weight increased slightly (Table II). During the first period (days 1-2), the food intake was low as compared with that in the second period (days 3-4), when the rats consumed more of the diet. After day 5, the rats in each group consumed almost constant amounts of each diet. The concentration of

*1 Japan SLC Inc., Hamamatsu, Japan.

*2 Oriental Yeast Co., Ltd., Tokyo, Japan.

*3 Kjeltec Auto System III; Tecator AB, Hoganas, Sweden.

*4 Shimadzu CL-7000 Autoanalyzer, Kyoto, Japan. 
Table II. Effects of Dietary Protein level on the Body Weight and Food Intake in Suspended or Non-suspended Rats for 10 Days

\begin{tabular}{|c|c|c|c|c|c|c|c|c|c|c|}
\hline \multicolumn{2}{|c|}{ Treatment } & \multicolumn{3}{|c|}{ Body weight } & \multicolumn{5}{|c|}{ Food intake } & \multirow{2}{*}{$\begin{array}{l}\text { Total food } \\
\text { intake for } \\
10 \text { days } \\
\text { (g/10 days) }\end{array}$} \\
\hline Group & Diet & $\begin{array}{l}\text { Initial } \\
(\mathrm{g})\end{array}$ & $\begin{array}{c}\text { Final } \\
(\mathrm{g})\end{array}$ & $\begin{array}{l}\text { Change } \\
\text { (g/10 days) }\end{array}$ & $\begin{array}{l}\text { Days } 1-2 \\
\text { (g/2 days) }\end{array}$ & $\begin{array}{l}\text { Days 3-4 } \\
\text { (g/2 days) }\end{array}$ & $\begin{array}{l}\text { Days } 5-6 \\
\text { (g/2 days) }\end{array}$ & $\begin{array}{l}\text { Days } 7-8 \\
\text { (g/2 days) }\end{array}$ & $\begin{array}{c}\text { Days } 9-10 \\
(\mathrm{~g} / 2 \text { days })\end{array}$ & \\
\hline \multicolumn{2}{|c|}{ Suspended rats } & & & & & & & & & \\
\hline \multicolumn{2}{|c|}{ 1. $5 \%$ Casein } & $130.2 \pm 1.9^{1}$ & $127.2 \pm 4.8^{\mathrm{ab}}$ & $-5.4 \pm 3.0^{\mathrm{a}}$ & $11.76 \pm 1.25^{\mathrm{a}}$ & $29.59 \pm 0.81^{\mathrm{bc}}$ & $25.68+3.50^{\mathrm{b}}$ & $25.47 \pm 1.61^{\mathrm{b}}$ & $27.14 \pm 2.07^{b}$ & $119.64 \pm 6.76^{\mathrm{c}}$ \\
\hline \multicolumn{2}{|c|}{ 2. $10 \%$ Casein } & $129.6 \pm 2.0$ & $136.2 \pm 3.1^{\mathrm{b}}$ & $6.6 \pm 3.0^{\mathrm{b}}$ & $13.07 \pm 2.73^{\mathrm{a}}$ & $30.59 \pm 1.27^{\mathrm{bc}}$ & $28.19 \pm 2.05^{b}$ & $28.06 \pm 2.92^{b}$ & $23.95 \pm 2.01^{\mathrm{ab}}$ & $123.87 \pm 4.86^{\mathrm{c}}$ \\
\hline \multicolumn{2}{|c|}{ 3. $20 \%$ Casein } & $127.5 \pm 1.9$ & $122.0 \pm 3.0^{\mathrm{a}}$ & $-5.5 \pm 2.7^{\mathrm{a}}$ & $13.45 \pm .0 .72^{\mathrm{a}}$ & $32.21 \pm 0.32^{\mathrm{c}}$ & $23.65 \pm 2.76^{\mathrm{ab}}$ & $23.17 \pm 1.29^{\mathrm{b}}$ & $21.61 \pm 1.59^{\mathrm{a}}$ & $114.10 \pm 2.84^{\mathrm{bc}}$ \\
\hline \multicolumn{2}{|c|}{ 4. $40 \%$ Casein } & $130.0 \pm 2.7$ & $125.8 \pm 4.2^{\mathrm{ab}}$ & $-4.3 \pm 2.0^{\mathrm{a}}$ & $11.91 \pm 0.87^{\mathrm{a}}$ & $28.83 \pm 1.25^{\mathrm{b}}$ & $21.28 \pm 1.97^{\mathrm{ab}}$ & $21.99 \pm 0.88^{\mathrm{ab}}$ & $21.11 \pm 0.77^{\mathrm{a}}$ & $105.11 \pm 3.59^{b}$ \\
\hline \multicolumn{2}{|c|}{ 5. $60 \%$ Casein } & $127.8 \pm 2.2$ & $116.2 \pm 2.8^{\mathrm{a}}$ & $-11.6 \pm 2.6^{\mathrm{a}}$ & $10.88 \pm 2.17^{\mathrm{a}}$ & $25.50 \pm 1.35^{\mathrm{a}}$ & $16.96 \pm 1.79^{\mathrm{a}}$ & $17.35 \pm 0.80^{\mathrm{a}}$ & $20.60 \pm 1.66^{a}$ & $91.29 \pm 3.14^{\mathrm{a}}$ \\
\hline \multicolumn{11}{|c|}{ Non-suspended rats } \\
\hline \multicolumn{2}{|c|}{ 6. $20 \%$ Casein } & $128.0 \pm 2.3$ & $200.8 \pm 4.5^{\mathrm{c}}$ & $72.8 \pm 2.6^{\mathrm{c}}$ & $30.52 \pm 0.61^{\mathrm{b}}$ & $35.95 \pm 0.62^{\mathrm{d}}$ & $36.16 \pm 0.63^{c}$ & $37.09 \pm 0.61^{\circ}$ & $36.11 \pm 1.51^{\circ}$ & $175.83 \pm 3.53^{\mathrm{d}}$ \\
\hline
\end{tabular}

1 Means \pm SEM for five rats per group. Means within a column not followed by the same letter are significantly different (Duncan's multiple range test, $p<0.05$ ). 
Table III. Effects of Dietary Protein Level on the Liver, Adrenal and Testis Weights in Suspended and Non-suspended Rats

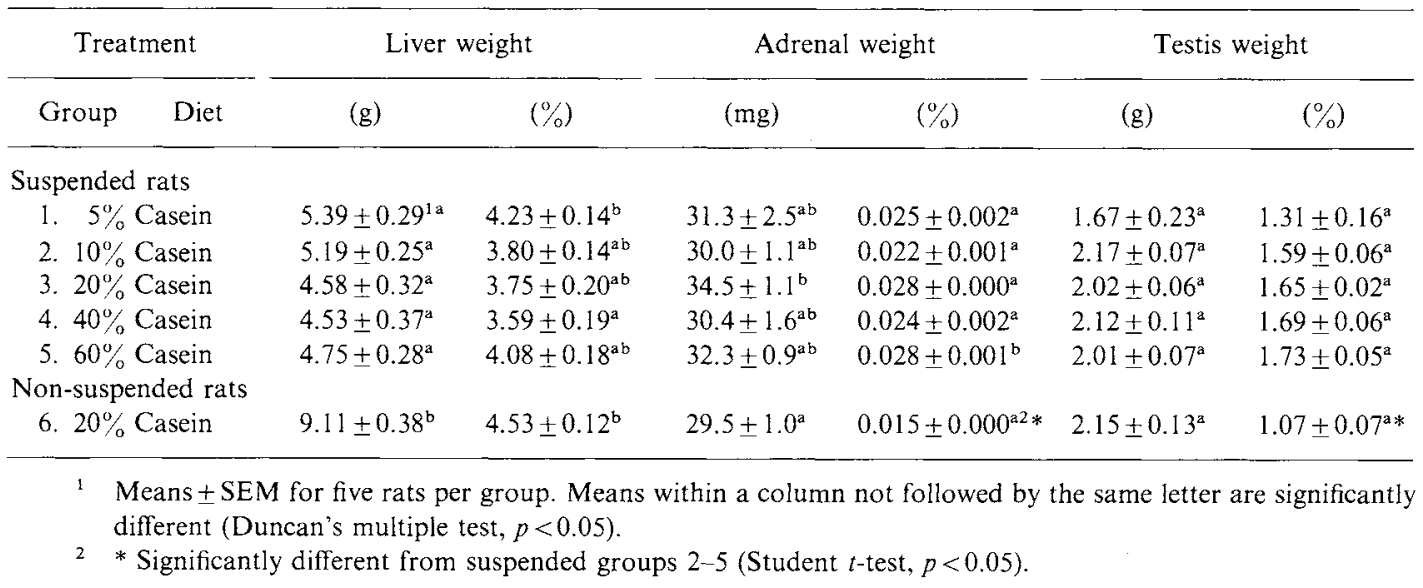

dietary protein affected the food intake, the total food intake over 10 days gradually decreasing with a stepwise increase in dietary protein.

Effects of suspension on the liver, adrenal, testis and muscle weights of rats fed on a diet with different protein contents

The liver weight of the suspended rats decreased significantly as compared with that of the non-suspended rats. The relative weight of the liver of the suspended rats also decreased stepwisely with the increase in the amount of dietary protein (with the exception of the $60 \%$ protein-group; Table III). The relative weights of adrenal and testis was increased significantly by suspension of the rats as compared with the values for the non-suspended rats. Especially with the suspended rats, an increase in supplementary protein caused a stepwise increase in the relative testis weight. The weight of the gastrocnemius muscle in the suspended rats was significantly decreased as compared with that in the non-suspended rats (Table IV). The relative values for the gastrocnemius muscle were almost the same for the suspended and non-suspended rats. The soleus muscle was decreased in weight significantly, to about $47 \%$, by suspension, and the relative weight of the soleus muscle also decreased as compared with that in the

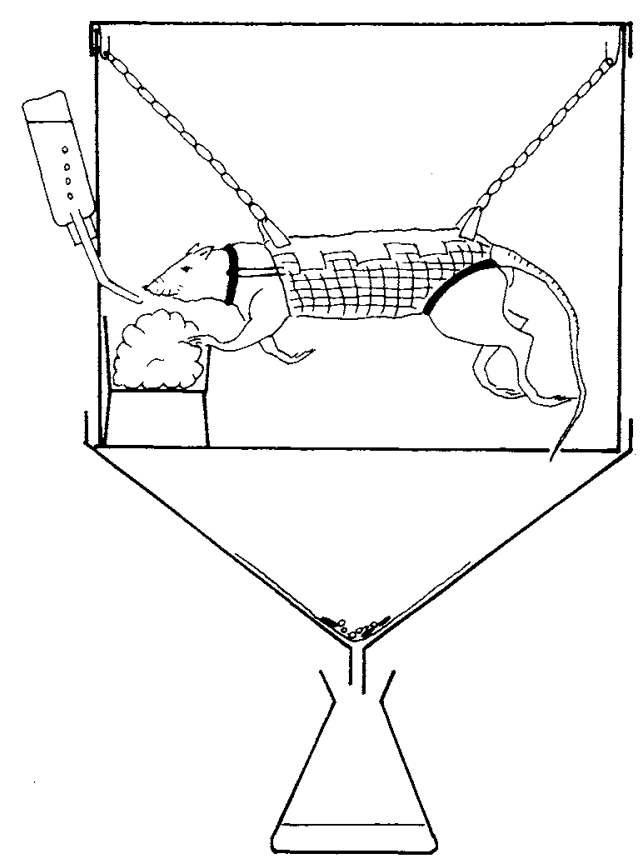

Fig. 1. A Rat in the Suspension Harness (described in Materials and Methods) and Metabolism Cage.

non-suspended rats. The degree of this reduction in soleus muscle weight by suspension was much greater than that of the decrease in weight of the gastrocnemius muscle. The concentrations of water and protein in the gastrocnemius muscle remained unchanged; however, in the case of the soleus muscle, these concentrations tended to be increased by sus- 
Table IV. Effects of Dietary Protein level on the Muscle (Gastrocnemius and Soleus) Weight and Composition in Suspended AND NON-SUSPENDED RATS

\begin{tabular}{|c|c|c|c|c|c|c|c|c|c|}
\hline \multicolumn{2}{|c|}{ Treatment } & \multicolumn{4}{|c|}{ Gastrocnemius muscle } & \multicolumn{4}{|c|}{ Soleus muscle } \\
\hline \multirow{2}{*}{\multicolumn{2}{|c|}{ Group Diet }} & \multicolumn{2}{|c|}{ Weight } & \multirow{2}{*}{$\begin{array}{c}\text { Water } \\
(\%)\end{array}$} & \multirow{2}{*}{$\begin{array}{l}\text { Protein } \\
(\mathrm{mg} / \mathrm{g})\end{array}$} & \multicolumn{2}{|c|}{ Weight } & \multirow{2}{*}{$\begin{array}{c}\text { Water } \\
(\%)\end{array}$} & \multirow{2}{*}{$\begin{array}{l}\text { Protein } \\
(\mathrm{mg} / \mathrm{g})\end{array}$} \\
\hline & & (g) & $(\%$ of body wt) & & & $(\mathrm{g})$ & $(\%$ of body wt) & & \\
\hline \multicolumn{10}{|c|}{ Suspended rats } \\
\hline 1. 5 & Casein & $1.329 \pm 0.051^{1 \mathrm{a}}$ & $1.05 \pm 0.03^{\mathrm{a}}$ & $76.4 \pm 0.2^{a}$ & $213.6 \pm 2.4^{a}$ & $0.065 \pm 0.004^{\mathrm{a}}$ & $0.051 \pm 0.002^{a}$ & $77.5 \pm 0.9^{a}$ & $228.6 \pm 10.2^{\mathrm{a}}$ \\
\hline 2. 10 & Casein & $1.562 \pm 0.03 \mathrm{l}^{\mathrm{a}}$ & $1.15 \pm 0.02^{\mathrm{a}}$ & $75.8 \pm 0.1^{\mathrm{a}}$ & $215.0 \pm 1.6^{\mathrm{a}}$ & $0.072 \pm 0.004^{\mathrm{a}}$ & $0.053 \pm 0.003^{\mathrm{a}}$ & $78.1 \pm 1.0^{\mathrm{a}}$ & $210.4 \pm 12.7^{a}$ \\
\hline 3. 20 & Casein & $1.339 \pm 0.033^{\mathrm{a}}$ & $1.10 \pm 0.03^{\mathrm{a}}$ & $75.5 \pm 0.1^{\mathrm{a}}$ & $222.3 \pm 0.7^{\mathrm{a}}$ & $0.062 \pm 0.001^{\mathrm{a}}$ & $0.051 \pm 0.002^{\mathrm{a}}$ & $76.3 \pm 0.8^{a}$ & $227.4 \pm 1.9^{\mathrm{a}}$ \\
\hline 4. 40 & Casein & $1.438 \pm 0.02 \mathrm{I}^{\mathrm{a}}$ & $1.15 \pm 0.03^{\mathrm{a}}$ & $75.6+0.2^{a}$ & $216.2 \pm 3.1^{\mathrm{a}}$ & $0.065 \pm 0.004^{\mathrm{a}}$ & $0.053 \pm 0.002^{\mathrm{a}}$ & $74.5 \pm 1.0^{\mathrm{a}}$ & $221.4 \pm 4.2^{\mathrm{a}}$ \\
\hline 5. 60 & Casein & $1.253 \pm 0.046^{\mathrm{a}}$ & $1.08 \pm 0.03^{\mathrm{a}}$ & $75.1 \pm 0.1^{\mathrm{a}}$ & $227.1 \pm 1.0^{\mathrm{a}}$ & $0.063 \pm 0.003^{\mathrm{a}}$ & $0.055 \pm 0.004^{\mathrm{a}}$ & $74.1 \pm 0.7^{\mathrm{a}}$ & $240.2 \pm 4.6^{\mathrm{a}}$ \\
\hline \multicolumn{10}{|c|}{ Non-suspended rats } \\
\hline 6. 20 & Casein & $2.262 \pm 0.05 \mathrm{I}^{\mathrm{a} 2 *}$ & $1.13 \pm 0.02^{\mathrm{a}}$ & $75.8 \pm 0.1^{\mathrm{a}}$ & $216.6 \pm 4.0^{\mathrm{a}}$ & $0.139 \pm 0.005^{\mathrm{a} *}$ & $0.069 \pm 0.002^{\mathrm{a} *}$ & $74.5 \pm 0.1^{\mathrm{a}}$ & $211.7 \pm 9.7^{\mathrm{a}}$ \\
\hline
\end{tabular}

1 Means \pm SEM for five rats per group. Means within a column not followed by the same letter are significantly different (Duncan's multiple range test, $p<0.05$ ).

* Significantly different from suspended groups 1-5 (Student $t$-test, $p<0.05$ ). 

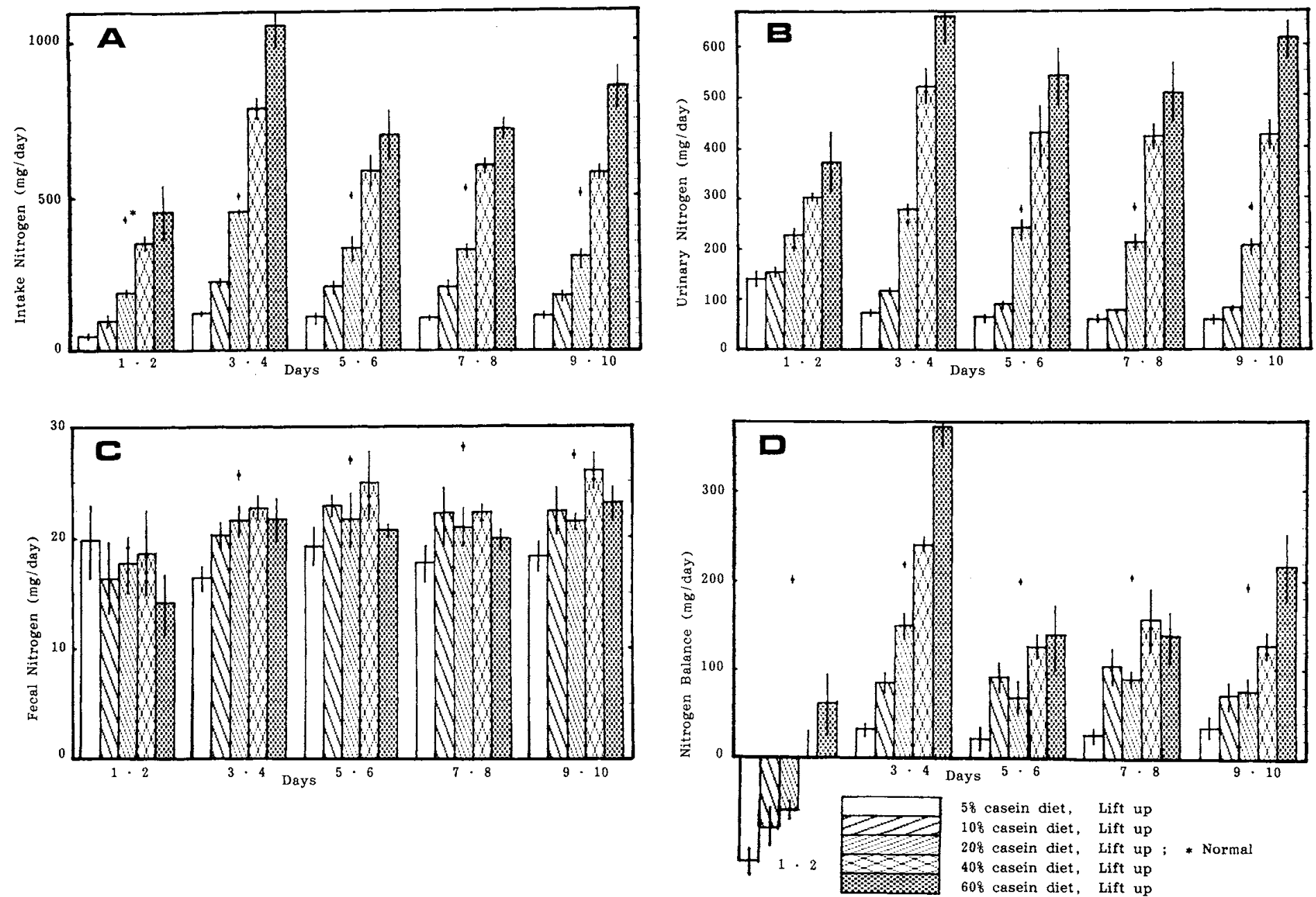

Fig. 2. Effects of Dietary Protein Level on the Nitrogen Intake (A), Urinary nitrogen (B), Fecal nitrogen (C) and Nitrogen Balance (D) in Suspended and Non-suspended Rats for 2-Day Periods.

Vertical bars indicate standard errors.

* Each value $(O)$ which is not a bar-graph shows the nitrogen concentration or balance in non-suspended control rats fed on a $20 \%$ casein diet. 
pension.

Effects of suspension on the nitrogen-balance (dietary, urinary and fecal nitrogen) and carcass composition of rats fed on a diet with different protein contents

The changes in nitrogen concentration of the ingested food, urine and feces for 2-day periods during the experimental period are shown in Figs. 2A, B and C, respectively. The concentration of ingested nitrogen gradually increased with the stepwise increase in dietary protein level, and after 5 days of feeding, the nitrogen intake in each diet group was constant. Nitrogen excretion in the urine also increased with the increase in dietary protein level, like the nitrogen intake. Fecal nitrogen excretion by the suspended or non-suspended rats was low, as compared with the nitrogen excretion in urine, and almost the same in each group. The nitrogen balance was then calculated from the amount of nitrogen ingested minus the urinary- and fecal-nitrogen concentrations for a 2-day period (Fig. 2D). During the first period (days 1-2), the nitrogen balance in the suspended rats fed on the 5,10 , 20 and $40 \%$ casein diets was negative, the value being dependent on the amount of dietary protein. Only in the $60 \%$ casein diet group was the nitrogen value positive. After 3 days of feeding, the nitrogen balance value in all the suspended rats fed on the test diets, regardless of the level of dietary protein, was positive, even in the low-protein diet group, the positive value being dependent on the level of dietary protein. The total nitrogen balance values in the suspended rats fed on the 5, 10, 20,40 and $60 \%$ casein diets for 10 days were $1.4 \pm 63.6$, $554.2 \pm 62.3,652.3 \pm 58.6,1308.0 \pm 131.4$ and $1965.4 \pm 177.4(\mathrm{mg} / 10$ days), respectively. (In the case of the non-suspended rats fed on the $20 \%$ casein diet, the total nitrogen balance value was $2053.1 \pm 69.3 \mathrm{mg} / 10$ days.)

The concentrations of total carcass protein and lipid ( $\mathrm{g}$ per total body weight) in the suspended rats decreased significantly, as compared with the values for non-suspended rats (Table V). However, the relative value of carcass protein (mg per $\mathrm{g}$ of body weight or \% of body weight) significantly increased in proportion to the increase in dietary protein, as compared with that in the non-suspended control group. On the other hand, the relative value of carcass lipid ( $\mathrm{mg}$ per $\mathrm{g}$ of body weight or $\%$ of body weight) was dramatically decreased by suspension, the degree of decrease being dependent on the level of dietary protein. The water concentration in the carcasses of the suspended rats was higher than that in the non-suspended rats.

Table V. Effect of Dietary Level on the Carcass Composition (Protein, Fat and Water) in SUSPENDED and Non-SUSPENDED RatS

\begin{tabular}{|c|c|c|c|c|c|c|c|}
\hline Treatment & \multicolumn{3}{|c|}{ Protein } & \multicolumn{3}{|c|}{ Fat } & \multirow{2}{*}{$\begin{array}{c}\text { Water } \\
(\% \text { of } \\
\text { body wt) }\end{array}$} \\
\hline Group Diet & $(\mathrm{mg} / \mathrm{g})$ & $\begin{array}{l}\text { (g/total } \\
\text { body wt) }\end{array}$ & $\begin{array}{c}(\% \text { of } \\
\text { body wt) }\end{array}$ & $(\mathrm{mg} / \mathrm{g})$ & $\begin{array}{l}(\mathrm{g} / \text { total } \\
\text { body wt) }\end{array}$ & $\begin{array}{c}(\% \text { of } \\
\text { body wt) }\end{array}$ & \\
\hline \multicolumn{8}{|l|}{ Suspended rats } \\
\hline 1. $5 \%$ Casein & $32.1 \pm 0.8^{1 \mathrm{a}}$ & $4.09 \pm 0.18^{\mathrm{a}}$ & $3.22 \pm 0.08^{\mathrm{a}}$ & $115.7 \pm 9.6^{\mathrm{a}}$ & $14.89 \pm 1.73^{\mathrm{a}}$ & $11.57 \pm 0.96^{\circ}$ & $85.2 \pm 0.2^{b}$ \\
\hline 2. $10 \%$ Casein & $34.2 \pm 0.2^{\mathrm{a}}$ & $4.66 \pm 0.10^{\mathrm{a}}$ & $3.42 \pm 0.03^{\mathrm{a}}$ & $100.8 \pm 5.1^{\mathrm{a}}$ & $14.00 \pm 0.79^{\mathrm{a}}$ & $10.09 \pm 0.51^{b c}$ & $86.4 \pm 0.5^{\mathrm{c}}$ \\
\hline 3. $20 \%$ Casein & $35.5 \pm 0.2^{\mathrm{a}}$ & $4.33 \pm 0.13^{\mathrm{a}}$ & $3.55 \pm 0.02^{\mathrm{a}}$ & $89.5 \pm 2.6^{\mathrm{a}}$ & $10.92 \pm 0.36^{\mathrm{a}}$ & $8.95 \pm 0.26^{b}$ & $87.5 \pm 0.2^{c}$ \\
\hline 4. $40 \%$ Casein & $35.6 \pm 0.4^{\mathrm{a}}$ & $4.48 \pm 0.12^{\mathrm{a}}$ & $3.56 \pm 0.04^{a}$ & $97.4 \pm 7.3^{a}$ & $12.41 \pm 1.26^{\mathrm{a}}$ & $9.74 \pm 0.73^{\mathrm{bc}}$ & $86.7 \pm 0.7^{c}$ \\
\hline 5. $60 \%$ Casein & $36.1 \pm 0.2^{\mathrm{a}}$ & $4.20 \pm 0.10^{\mathrm{a}}$ & $3.62 \pm 0.02^{a}$ & $71.3 \pm 2.9^{\mathrm{a}}$ & $8.37 \pm 0.35^{\mathrm{a}}$ & $7.13 \pm 0.30^{\mathrm{a}}$ & $89.2 \pm 0.2^{\mathrm{d}}$ \\
\hline \multicolumn{8}{|c|}{ Non-suspended rats } \\
\hline 6. $20 \%$ Casein & $28.5 \pm 0.5^{\mathrm{a} 2 *}$ & $5.59 \pm 0.22^{a *}$ & $2.85 \pm 0.06^{\mathrm{a} *}$ & $182.8 \pm 5.3^{\mathrm{a} *}$ & $36.74 \pm 1.41^{2 *}$ & $18.28 \pm 0.53^{\mathrm{d} *}$ & $78.8 \pm 0.4^{\mathrm{a} *}$ \\
\hline
\end{tabular}


Table Vi. Effects of Dietary Protein Level on the Serum Proteins in SUSPENDED AND NON-SUSPENDED RATS

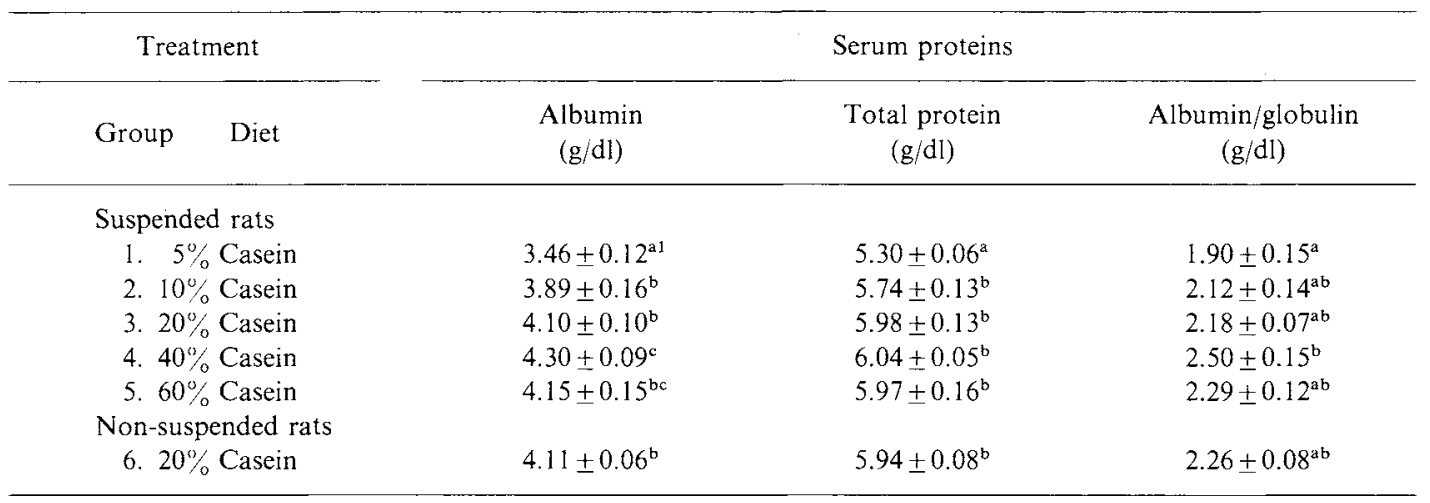

1 Means $\pm S E M$ for five rats per group. Means within a column not followed by the same letter are significantly different (Duncan's multiple range test, $p<0.05$ ).

Effect of suspension on serum proteins in the rats fed on a diet with different protein contents

Changes in the concentrations of serum albumin and proteins were dependent on the levels of dietary protein: that is, a low protein diet caused decreases in these serum levels (Table VI). Suspension did not affect the concentrations of serum proteins. The serum albumin value per globulin was affected by the dietary protein level, but not by suspension.

\section{Discussion}

The present model consists of a suspended rat whose weight was transferred to the abdominal surface, the forelimbs and hindlimbs being non-load-bearing for 10 days. The objectives of this study were to assess the effect of weightlessness and muscle atrophy on hypokinesia, because one of the most consistent and repeatedly observed responses to bed rest, immobilization and weightlessness is increased nitrogen loss, which often results in a negative nitrogen balance. ${ }^{1-4)}$ The hypokinetic rat model allows the prediction of changes in the pattern of nitrogen metabolism during these different types of hypokinesia. ${ }^{14)}$ In this study, a weight loss in the rats due to suspension was observed, and this loss may have been due to the reduced food intake, as compared with the non-suspended rats. When the rats were fed on the $10 \%$ casein diet for 10 days, the body weight increased slightly (Table II). Usually, the protein requirement level for casein is about $20 \%{ }^{18)}$; therefore, under the conditions of suspension hypokinesia, the protein requirement level may have been lower compared with that of the non-suspended rats.

The relative weights of the adrenal and testis of each suspended rat were significantly increased, as compared with those in the nonsuspended rats when judged with the Student $t$-test (Table III). Suspension stress may affect the adrenal weight, and changes in fluid and electrolyte shifts may affect the testis weight. On the other hand, this adrenal hypertrophy may be consistent with the hypothesis of glucocorticoid-mediated muscle catabolism. ${ }^{19}$ ) Generally, it is believed that pharmacologic doses of glucocorticoids are necessary for steroid-induced muscle atrophy. ${ }^{20)}$ Atrophy in the gastrocnemius and soleus muscles was observed after 10 days of suspension, especially in the soleus muscle, a postural antigravity muscle composed mainly of slow twitch fibers. ${ }^{22)}$ Musacchia et al. ${ }^{211}$ reported the following muscle mass loss order: soleus $>$ gastrocnemius $=$ plantaris $>$ extensor digitorum longus, the gastrocnemius showing losses during the first week but no significant loss during the second week of sus- 
Table ViI. Effect of Dietary Protein Level on Various Organ Weights in Suspended and Non-SUSPENDED RatS for 10 Days

\begin{tabular}{|c|c|c|c|c|c|c|c|}
\hline \multicolumn{2}{|c|}{ Treatment } & \multicolumn{2}{|c|}{ Brain } & \multicolumn{2}{|c|}{ Lung } & \multicolumn{2}{|c|}{ Kidney } \\
\hline Group & Diet & (g) & $(\%)$ & (g) & $(\%)$ & (g) & $(\%)$ \\
\hline \multicolumn{8}{|c|}{ Non-suspended rats } \\
\hline 1. $0 \%$ & sein & $1.742 \pm 0.017^{1 \mathrm{~b}}$ & $1.21 \pm 0.03^{b}$ & $0.692 \pm 0.030^{\circ}$ & $0.482 \pm 0.026^{\mathrm{ab}}$ & $1.019 \pm 0.037^{\mathrm{a}}$ & $0.708 \pm 0.009^{b}$ \\
\hline 2. $10 \%$ & $\operatorname{sein}$ & $1.761 \pm 0.021^{\mathrm{b}}$ & $0.83 \pm 0.01^{\mathrm{a}}$ & $0.872 \pm 0.041^{\circ}$ & $0.410 \pm 0.020^{a}$ & $1.376 \pm 0.046^{c}$ & $0.645 \pm 0.011^{a}$ \\
\hline 3. $25 \%$ & sein & $1.811 \pm 0.022^{c}$ & $0.84 \pm 0.01^{a}$ & $0.880 \pm 0.032^{\mathrm{c}}$ & $0.406 \pm 0.014^{\mathrm{a}}$ & $1.556 \pm 0.035^{\mathrm{d}}$ & $0.718 \pm 0.008^{\mathrm{b}}$ \\
\hline 4. $40 \%$ & sein & $1.810 \pm 0.017^{\mathrm{c}}$ & $0.85 \pm 0.01^{\mathrm{a}}$ & $0.878 \pm 0.060^{c}$ & $0.410 \pm 0.021^{\mathrm{a}}$ & $1.726 \pm 0.047^{\mathrm{e}}$ & $0.808 \pm 0.012^{\mathrm{c}}$ \\
\hline \multicolumn{8}{|c|}{ Suspended rats } \\
\hline 5. $\quad 0 \%$ & sein & $1.730 \pm 0.010^{\mathrm{ab}}$ & $1.41 \pm 0.04^{\mathrm{c}}$ & $0.572 \pm 0.044^{\mathrm{a}}$ & $0.438 \pm 0.040^{\mathrm{ab}}$ & $0.985 \pm 0.025^{\mathrm{a}}$ & $0.805 \pm 0.016^{\mathrm{c}}$ \\
\hline 6. $10 \%$ & sein & $1.701 \pm 0.012^{\mathrm{ab}}$ & $1.31 \pm 0.04^{b c}$ & $0.644 \pm 0.027^{\mathrm{ab}}$ & $0.493 \pm 0.019^{\mathrm{ab}}$ & $1.076 \pm 0.026^{\mathrm{ab}}$ & $0.823 \pm 0.009^{c}$ \\
\hline 7. $25 \%$ & isein & $1.685 \pm 0.013^{\mathrm{a}}$ & $1.32 \pm 0.03^{c}$ & $0.584 \pm 0.032^{\mathrm{ab}}$ & $0.460 \pm 0.034^{\mathrm{ab}}$ & $1.161 \pm 0.023^{\mathrm{b}}$ & $0.906 \pm 0.016^{\mathrm{d}}$ \\
\hline 8. $40 \%$ & sein & $1.711 \pm 0.013^{\mathrm{ab}}$ & $1.34 \pm 0.05^{c}$ & $0.660 \pm 0.013^{\mathrm{ab}}$ & $0.519 \pm 0.024^{\mathrm{b}}$ & $1.200 \pm 0.034^{b}$ & $0.937 \pm 0.019^{d}$ \\
\hline
\end{tabular}

Table VII. CONTINUED

\begin{tabular}{|c|c|c|c|c|c|c|c|}
\hline \multicolumn{2}{|c|}{ Treatment } & \multicolumn{2}{|c|}{ Adrenals } & \multicolumn{2}{|c|}{ Gastrocnemius muscle } & \multicolumn{2}{|c|}{ Soleus muscle } \\
\hline Group & Diet & (g) & $(\%)$ & (g) & $(\%)$ & (g) & $(\%)$ \\
\hline \multicolumn{8}{|c|}{ Non-suspended rats } \\
\hline 1. $0 \%$ & asein & $22.0 \pm 1.1^{\mathrm{a}}$ & $0.015 \pm 0.001^{a}$ & $1.779 \pm 0.043^{\mathrm{b}}$ & $1.24 \pm 0.02^{\mathrm{b}}$ & $0.112 \pm 0.004^{b}$ & $0.078 \pm 0.001^{\mathrm{c}}$ \\
\hline 2. $10 \%$ & asein & $23.6 \pm 1.4^{\mathrm{ab}}$ & $0.011 \pm 0.001^{\mathrm{a}}$ & $2.366 \pm 0.126^{\mathrm{c}}$ & $1.11 \pm 0.05^{\mathrm{a}}$ & $0.149 \pm 0.004^{\mathrm{d}}$ & $0.070 \pm 0.002^{\mathrm{b}}$ \\
\hline 3. $25 \%$ & asein & $29.2 \pm 0.9^{b c}$ & $0.014 \pm 0.000^{\mathrm{a}}$ & $2.542 \pm 0.042^{c}$ & $1.16 \pm 0.0 \mathrm{I}^{\mathrm{a}}$ & $0.141 \pm 0.004^{\mathrm{cd}}$ & $0.065 \pm 0.003^{\mathrm{b}}$ \\
\hline 4. $40 \%$ & asein & $27.6 \pm 0.9^{b c}$ & $0.013 \pm 0.000^{\mathrm{a}}$ & $2.485 \pm 0.059^{\mathrm{c}}$ & $1.16 \pm 0.0 \mathrm{I}^{\mathrm{a}}$ & $0.138 \pm 0.006^{c}$ & $0.065 \pm 0.003^{\mathrm{b}}$ \\
\hline \multicolumn{8}{|c|}{ Suspended rats } \\
\hline 5. $0 \%$ & asein & $26.3 \pm 0.8^{b}$ & $0.022 \pm 0.002^{\mathrm{b}}$ & $1.328 \pm 0.029^{\mathrm{a}}$ & $1.08 \pm 0.02^{\mathrm{a}}$ & $0.057 \pm 0.003^{\mathrm{a}}$ & $0.045 \pm 0.002^{\mathrm{a}}$ \\
\hline 6. $10 \%$ & asein & $31.1 \pm 1.8^{\mathrm{c}}$ & $0.024 \pm 0.002^{\mathrm{bc}}$ & $1.449 \pm 0.054^{\mathrm{a}}$ & $1.10 \pm 0.01^{\mathrm{a}}$ & $0.062 \pm 0.003^{\mathrm{a}}$ & $0.047 \pm 0.002^{\mathrm{a}}$ \\
\hline 7. $25 \%$ & asein & $34.8 \pm 1.1^{\mathrm{cd}}$ & $0.027 \pm 0.001^{\mathrm{c}}$ & $1.510 \pm 0.055^{\mathrm{a}}$ & $1.13 \pm 0.03^{\mathrm{a}}$ & $0.058 \pm 0.003^{\mathrm{a}}$ & $0.044 \pm 0.002^{\mathrm{a}}$ \\
\hline $8.40 \%$ & asein & $35.6 \pm 1.4^{\mathrm{d}}$ & $0.028 \pm 0.001^{\mathrm{c}}$ & $1.504 \pm 0.074^{\mathrm{a}}$ & $1.16 \pm 0.03^{\mathrm{a}}$ & $0.060 \pm 0.003^{\mathrm{a}}$ & $0.047 \pm 0.002^{\mathrm{a}}$ \\
\hline
\end{tabular}

Table VII. CONTINUED

\begin{tabular}{|c|c|c|c|c|c|c|c|}
\hline \multicolumn{2}{|c|}{ Treatment } & \multicolumn{2}{|c|}{ Spleen } & \multicolumn{2}{|c|}{ Liver } & \multicolumn{2}{|c|}{ Testes } \\
\hline Group & Diet & $(\mathrm{g})$ & $(\%)$ & (g) & $(\%)$ & (g) & $(\%)$ \\
\hline \multicolumn{8}{|c|}{ Non-suspended rats } \\
\hline 1. $0 \%$ & asein & $0.248 \pm 0.017^{\mathrm{a}}$ & $0.172 \pm 0.009^{\mathrm{a}}$ & $5.08 \pm 0.23^{\mathrm{a}}$ & $3.53 \pm 0.13^{\mathrm{a}}$ & $2.13 \pm 0.11^{\mathrm{b}}$ & $1.48 \pm 0.05^{\mathrm{b}}$ \\
\hline 2. $10 \%$ & asein & $0.448 \pm 0.015^{\mathrm{b}}$ & $0.210 \pm 0.007^{\mathrm{b}}$ & $8.81 \pm 0.25^{\mathrm{b}}$ & $4.13 \pm 0.05^{b}$ & $2.30 \pm 0.07^{\mathrm{b}}$ & $1.08 \pm 0.03^{\mathrm{a}}$ \\
\hline 3. $25 \%$ & asein & $0.510 \pm 0.024^{c}$ & $0.235 \pm 0.009^{c}$ & $9.54 \pm 0.17^{b c}$ & $4.41 \pm 0.08^{\mathrm{bc}}$ & $2.35 \pm 0.02^{\mathrm{b}}$ & $1.08 \pm 0.02^{\mathrm{a}}$ \\
\hline 4. $40 \%$ & asein & $0.544 \pm 0.026^{\mathrm{c}}$ & $0.254 \pm 0.007^{\mathrm{c}}$ & $9.92 \pm 0.43^{c}$ & $4.63 \pm 0.13^{c}$ & $2.31 \pm 0.04^{b}$ & $1.09 \pm 0.01^{a}$ \\
\hline \multicolumn{8}{|c|}{ Suspended rats } \\
\hline 5. $0 \%$ & asein & $0.253 \pm 0.010^{\mathrm{a}}$ & $0.206 \pm 0.009^{\mathrm{b}}$ & $4.64 \pm 0.25^{\mathrm{a}}$ & $3.76 \pm 0.12^{\mathrm{a}}$ & $1.48 \pm 0.13^{\mathrm{a}}$ & $1.19 \pm 0.08^{\mathrm{ab}}$ \\
\hline $6.10 \%$ & asein & $0.290 \pm 0.015^{a}$ & $0.221 \pm 0.006^{\mathrm{bc}}$ & $4.94 \pm 0.28^{\mathrm{a}}$ & $3.77 \pm 0.15^{\mathrm{a}}$ & $1.64 \pm 0.12^{\mathrm{a}}$ & $1.25 \pm 0.06^{\mathrm{ab}}$ \\
\hline $7.25 \%$ & asein & $0.280 \pm 0.011^{\mathrm{a}}$ & $0.218 \pm 0.007^{\mathrm{bc}}$ & $4.84 \pm 0.21^{\mathrm{a}}$ & $3.76 \pm 0.11^{\mathrm{a}}$ & $1.79 \pm 0.14^{\mathrm{ab}}$ & $1.38 \pm 0.10^{\mathrm{b}}$ \\
\hline $8.40 \%$ & asein & $0.284 \pm 0.018^{\mathrm{a}}$ & $0.220 \pm 0.007^{b c}$ & $4.87 \pm 0.37^{a}$ & $3.76 \pm 0.13^{\mathrm{a}}$ & $1.67 \pm 0.21^{\mathrm{a}}$ & $1.27 \pm 0.13^{\mathrm{ab}}$ \\
\hline
\end{tabular}

1 Means \pm SEM for five (non-suspended) or eight (suspended) rats per group. Means within a column not followed by the same letter are significantly different (Duncan's multiple range test, $p<0.05$ ). 
pension. Our results support these different muscle loss responses to suspension. Space flight causes atrophy of the skeletal muscles. $^{5-7)}$ A morphological change accompanied by a metabolic alteration in the rat soleus muscle was also induced by exposure to weightlessness. ${ }^{5.24 .25}$ ) This suggests that the muscle fiber size decreased, since the number of muscle fibers presumably remained constant. It was also reported that, in atrophic muscles, the absolute DNA level did not change, but the RNA content decreased in addition to a reduction of RNA/DNA. ${ }^{23)}$ Therefore, the capacity for protein synthesis in the muscles of suspended animals may decrease. The weights of other organs (brain, lung, kidney and spleen) were determined in our preliminary study (the experimental conditions being almost the same as those in this experiment with dietary protein levels of 0,10 , 25 and $40 \%$, and a suspension period of 10 days; Table VII). The relative weight of the brain was significantly increased by suspension. The results of related studies with animal subjects also support our contention that the hypokinetic rat model is comparable to weightlessness in rats. ${ }^{5}$ ) These investigators reported that rats, after 22.5 days of flight under conditions of weightlessness (Cosmos690), lost significant weight in the soleus and gastrocnemius muscles by 25 and $19 \%$, respectively.

The total nitrogen balance ( $\mathrm{mg} / 10$ days) was unexpectedly positive in all the suspended groups. Only in the first period during days $1-$ 2 was the nitrogen balance in the suspended rats fed on the 5, 10, 20 and $40 \%$ casein diets negative. These results are in agreement with those of human Skylab studies; that is, a negative nitrogen balance in flight persisted for the first 3 weeks, and after about a month, it varied from negative to slightly positive. ${ }^{13}$ The degree of the positive nitrogen balance value was dependent on the dietary protein level (stepwisely positive), but the change in body weight (Table II) was negatively dependent on the dietary protein level; i.e., the nitrogen balance was positive, but the body weight decreased. Therefore, the concentrations of body proteins, fat and water were determined (Table V). The total concentrations of body protein and lipid in the suspended rats decreased significantly, but the relative carcass protein value increased as compared with that in the non-suspended group. On the other hand, the relative carcass lipid value was significantly decreased by suspension; therefore, the main loss in body weight may be considered to be due to the reduction in body lipid. The protein concentration in the hindlimb muscles of the suspended rats tended to increase, and this could have been due to a fluid shift toward the head following the headdown tilted suspension. As the suspension hypokinesia caused weightlessness and a loss of body lipid, the concentrations of serum albumin and globulin were determined as possible criteria for identifying the nutritional state. As a result, the serum protein levels were found not to be affected by suspension.

When rats were held with the suspension harness (hypokinesia/hypodynamia) shown in Fig. 1, the results obtained as to weightlessness of a reduction of appetite, muscle atrophy, etc. were correlated with those of a human "metabolic balance study" in space flight. ${ }^{1-7)}$ Metabolic changes or adaptation caused by suspension may resemble the physiological phenomena caused by prolonged bed rest. Therefore, using this suspension model, further investigations on basic medical problems in geriatrics and health guarantees in space flight will be needed.

\section{References}

1) J. E. Deitrick, G. D. Whedon and E. Shorr, Am. J. Med., 4, 3 (1948).

2) J. D. MacDougal, G. R. Ward, D. G. Sale and J. R. Sutton, J. Appl. Physiol.: Respirat. Environ. Exercise Physiol., 43, 700 (1977).

3) P. C. Rambaut, M. C. Smith, Jr., C. S. Leach, G. D. Whedon and J. Reid, Fed. Proc., 36, 1678 (1977).

4) G. D. Whedon, L. Lutwak, P. C. Rambaut, M. W. Whittle, J. Reid, M. C. Smith, C. Leach, C. R. Stadler and D. D. Sanford, Aviat. Space Environ. Med., 47, 391 (1976).

5) E. I. Ilyina-Kakueva, V. V. Portugalov and N. P. 
Kivenkova, Aviat. Space Environ. Med., 47, 700 (1976).

6) J. J. Leonard, C. S. Leach and P. C. Rambaut, Am. J. Clin. Nutr., 38, 667 (1983).

7) V. S. Oganov and A. N. Patapov, Life Sci. Space Res., 19, 137 (1976).

8) F. W. Booth, J. Appl. Physiol:: Respirat. Environ. Exercise Physiol., 43, 656 (1977).

9) I. D. Pestov and S. J. Gerathewohl, in "Foundations of Space Biology and Medicine," Vol. 2, National Aeronautics and Space Administration, Washington DC, 1975.

10) W. E. Thornton, in "Anthropometric Source Book," Vol. 1., NASA Reference Publication 1024, National Aeronautics and Space Administration, Washington DC, 1978.

11) A. S. Ushakov, T. A. Smirnova, G. C. Pitts, N. Pace, A. H. Smith and D. F. Rohlmann, Physiologist, 23, S41 (1980).

12) J. E. Greenleaf, E. M. Bernauer, L. T. Juhos, H. L. Young, J. T. Morse and R. W. Staley, J. Appl. Physiol.: Respirat. Environ. Exercise Physiol., 43, 126 (1977).

13) C. S. Leach and P. C. Rambaut, in "Biomedical Results from Skylab," ed. by R. S. Johnston and L. F. Dietlein, NASA SP-377 National Aeronautics and
Space Administration, Washington DC, 1977, p. 204.

14) X. J. Musacchia, D. R. Deavers, G. A. Meininger and T. P. Davis, J. Appl. Physiol.: Respirat. Environ. Exercise Physiol., 48, 479 (1980).

15) J. Folch, M. Lees and G. H. S. Stanley, J. Biol. Chem., 226, 497 (1957).

16) O. H. Lowry, N. J. Rosebrough, A. L. Farr and R. J. Randall, J. Biol. Chem., 193, 265 (1951).

17) D. B. Duncan, Biometrics, 13, 164 (1957).

18) H. Yokogoshi, Y. Sakuma and A. Yoshida, J. Nutr., 110, 1347 (1980).

19) D. R. Deavers, X. J. Musacchia, G. A. Meininger and T. P. Davis, Fed. Proc., 38, 1051 (1979).

20) E. R. Ramey, in "Handbook of Physiology," Vol. VI., Am. Physiol. Soc., Sect. 7, Washington DC, 1975 , p. 245.

21) X. J. Musacchia, J. M. Steffen and D. R. Deavers, Aviat. Space Environ. Med., 54, 1015 (1983).

22) R. I. Close, Physiol. Rev., 52, 192 (1972).

23) J. M. Steffen and X. J. Musacchia, Am. J. Physiol., 247, R728 (1984).

24) L. A. Chui and K. R. Castleman, Physiologist, 23, S76 (1980).

25) R. D. Fell, L. B. Gladden, J. M. Steffen and X. J. Musacchia, J. Appl. Physiol., 58, 65 (1985). 